Stefano Zamboni, scj

Alphonsian Academy, Rome

zamstefano@yahoo.it

DOI: http://dx.doi.org/10.12775/BPTh.2017.008
Biblica

et

Patristica

Thoruniensia

10 (2017) 2: 179-195

ISSN (print) 1689-5150

ISSN (online) 2450-7059

\title{
Natural Law, Divine Law and Revealed Morality in the Summa Theologica: Continuity and Tensions
}

\section{Prawo naturalne, prawo Boże i moralność objawiona w Summa Theologica: ciągłość i napięcia*}

\begin{abstract}
The author reflects on the context in which Thomas treats of the natural law, i.e. the relations, relationships, and tensions highlighted by this concept, such as the meaning of the concept of law, the disturbing presence of sin, the relationship between natural reason and moral precepts, the role of revelation within the natural order, and the overflowing fulfillment of Christ's love.
\end{abstract}

Streszczenie. Autor analizuje kontekst, w jakim św. Tomasz z Akwinu rozważa naturalne prawo, np. stosunki, relacje i napięcia podkreślone przez ten koncept, takie jak: znaczenie pojęcia prawa, zaburzająca obecność grzechu, relacja pomiędzy naturalnym rozumem a nakazami moralnymi, rola objawienia zawierająca się w naturalnym porządku i rozlewające się wypełninienie Chrystusowej miłości.

Keywords: natural Law; concept of law; divine law in the thought of Aquinas; the Old law and the New law; the Summa Theologica.

Słowa kluczowe: prawo naturalne; prawo Boże; moralność objawiona.

7 he fact that the International Theological Commission has felt the need to compose a document devoted to natural law (In Search of a Universal Ethic: A New Look at the Natural Law, 2009) is clearly indicative that this category today is in crisis, because one usually does not produce written documents when a topic is completely resolved and settled. Moreover, the former Cardinal Ratzinger, in his famous dialogue with Jürgen Habermas in 2004, recognized

I would like to express my deep gratitude to Fr. Tony Hollowell who translated the text into English and to professors Seán Cannon and Martin McKeever for their revision. 
that the Catholic Church has spent centuries developing the concept of natural law but «unfortunately this tool is no longer sharp». ${ }^{1}$

The objections to the classical theory of natural law are well known and we will not discuss them in detail here. Just remember that these objections come from very diverse arguments: there are challenges posed by modern Philosophy (such as the is / ought critique or challenges to the classical concept of nature); challenges posed by modern physical and natural / life sciences (especially by modern Darwinian thinking and neurosciences); and the challenges posed by theology itself (particularly by the Protestant tradition). ${ }^{2}$

Of course, these are all challenges that Thomas did not know but which he certainly would have liked to answer. But not being able to question Thomas directly, it is my intent in this conference to try to capture that which, in my opinion, is both stimulating about Thomas' reflections on law and which is not sufficiently explored in moral theology today. To do this, I do not intend to address the issue of natural law in recto, but in verso. What do I mean by this?

If I ask a student during an exam to tell me what the natural law actually is according to Thomas, I expect first of all to hear the definition that is given in I-II,91,2, where natural law is defined as "participation of the eternal law in a rational creature (participatio legis aeternae in rationali creatura)». ${ }^{3}$ If I ask this same student how the natural law works, I expect a reference to inclinationes naturales found in Article 2 of quaestio 94, which is the most famous article in the Summa on this subject. If I am dealing with a particularly brilliant student, he or she will be able to note that the different inclinations correspond to the development of the various components of ethics: ethics of physical life; sexual and family ethics; religious and social ethics. Only after the student has answered these two questions can I ask a third question: what is the relationship between natural law and divine law in the thought of Aquinas? Here sometimes the student becomes pale in the face and does not know how to articulate an answer... And yet, in my opinion, it is precisely here that one finds the most interesting and engaging considerations.

1 J. Habermas, J. Ratzinger, The Dialectics of Secularization: On Reason and Religion, p. 50.

For more on this topic, see the first part of the following doctoral thesis which was recently defended at the Accademia Alfonsiana: B. M. Dolan, The Continuing Vitality of the Catholic Tradition of Natural Law. Contemporary Catholic Responses to the Critique of Natural Law.

3 My citations come from the following English translation: St. Thomas Aquinas, The Summa Theologica (Benziger Bros. edition, 1947) Translated by Fathers of the English Dominican Province: http://dhspriory.org/thomas/summa/ 
This is what I meant when I spoke about a reading of natural law in verso: I will address, not the most central topics, but rather the context in which Thomas treats of the natural law; the relations, relationships, and tensions highlighted by this concept, such as the meaning of the concept of law, the disturbing presence of sin, the relationship between natural reason and moral precepts, the role of revelation within the natural order, and the overflowing fulfillment of Christ's love.

\section{Natural Law as a theological concept}

Thomas' treatise on the law reveals its theological dimensions in his foundational premise that «the extrinsic principle moving to good is God, Who both instructs us by means of His Law, and assists us by His Grace» (I-II,90 pr.). In this way Thomas puts side by side the function of the law and that of grace, which are united by the fact that they come from God: it is through these two modes of "instruction" and "assistance" that God directs us from the outside.

Already this simple observation shows how extremely difficult it is to find agreement between Thomas' perspective and those who somehow want to separate natural law from the question of God. We see this in the case of someone like John Finnis who says in Natural Law and Natural Rights that he proposes «a rather elaborate sketch of a theory of natural law without needing to advert to the question of God's existence or nature or will» ${ }^{4}$, although at other points he clarifies and mitigates this statement. ${ }^{5}$

4 Second Edition, Oxford University Press, 2011, p. 49: file://C:/Users/zamst/Downloads/John\%20Finnis\%20Natural\%20Law\%20and\%20Natural\%20Rights\%20Clarendon\%20Law\%20\%202011.pdf

5 Yet in Chapter 13, he acknowledges that without the philosophical consideration of God, the entire theory is shown to be weak. In Chapter 13 of Natural Law and Natural Rights Finnis notes that Thomas spoke of the natural law as participation in the eternal law, where "participation" implies both the concept of "causality" and "similarity" (and therefore the natural law participates in the eternal law as it is caused by something similar). From here Finnis reflects a bit on what the existence of God implies and on what this means for practical reason. He argues: a) the uncaused cause of the world does not directly assist us in answering practical questions; b) the limitation of "natural reasoning" leaves somehow "subjective" and "questionable" the whole natural law theory; c) "natural reasoning" can speculatively postulate that the uncaused cause exists in something like the mode of personal life, and that its causality has some analogy to the intelligent self-direction and intentionality of human creative decision; d) if these speculations and hopes (i.e. the hope that the uncaused cause might reveal itself to be lovable) were confirmed, a more basic account of obligation would become possible (cfr. pages 405-406). The rather problematic 
As an alternative to this position, one could cite the works of Jean Porter. Going against the manualist tradition, which has a static and abstract conception of natural law, this American theologian tries to reconstruct the development of the concept without hiding the differences, tensions, and difficulties present in medieval theology. She also shows how, within this reconstruction, the concept of natural law in the Middle Ages is eminently theological and precisely how this theological account of the natural law may permit the development of a promising proposal for the questions of today. ${ }^{6}$

But in what sense must one speak of the theological nature of the natural law? A first glance at how to deal with the natural law in the Summa Theologica reveals that, for Aquinas, the natural law was part of a synthesis which embraced eternal, divine, and human law. But it is not only the context which informs us: it is also the intrinsic meaning of the natural law that calls for a theological understanding, a reason informed by faith.

The following words of Paul McKeever, written fifty years ago, still maintain their full significance for us today: natural law «was theological in context and nature. That it was theological in context needs, I believe, no argument. That it was theological in nature can be argued not only because of the identification of the precepts of the Bible with the precepts of natural law, but because natural law, itself part of a larger synthesis, was articulated in quest of understanding the foundations, not only of a natural morality, but of the supernatural morality of the Gospel itself». ${ }^{7}$ The precepts of natural law do not constitute a systematic code; it is not some legal handbook with formulaic responses to every particu-

framework evolves in his successive published works, for example in Aquinas: Moral, Political, and Legal Theory (Oxford University Press, 1998), where he clearly acknowledges the existence and the importance of the order through which God rules the world.

6 «In this book, I will develop a theological account of the natural law which takes its starting point and orientation from the concept of the natural law developed by scholastic jurists and theologians in the twelfth and thirteen centuries» (Nature as Reason. A Thomistic theory of the natural law, W.B. Eerdmans, 2005, 5). Compare this to what the same author also says in Natural and Divine Law. Reclaiming the Tradition for Christian Ethics, W.B. Eerdmans, 2005, 17: «Contrary to what is commonly assumed, medieval natural law thinkers did not attempt to derive moral principles from a supposedly self-evident and fixed conception of human nature. The concept of nature was a theological and not merely a philosophical notion for them, thanks to the extensive work on the theological significance of the natural world that began early in the twelfth century. Building on this work, taken together with key scriptural texts from Genesis and the Pauline letters, they developed a theological conception of human nature that enabled them to distinguish between those aspects of our nature that are normative, and those which are not».

7 P. E. McKeever, Theology and Natural Law, pp. 223-237. The citation comes from page 232 . 
lar question. Although the treatise on law and the question of natural law are certainly elements of a philosophy of natural law and of natural right, we are in the presence of a theological treatise, which is inserted within the broader context of salvation history.

This is what I would briefly like to demonstrate, starting from three questions which the manualist tradition has not explored sufficiently: the relationship between natural law and, respectively, the drama of sin, the old law and the new law.

\section{The drama of $\sin$}

In expounding on the different types of law, Thomas wonders whether there is, next to the eternal law, natural law, human law and divine law, even «a law of sin» (I-II,91,6). At a closer look, however, Thomas is not really talking about sin, but about fomes, i.e. «an incentive to evil» ( $\left.\mathrm{ad} 1^{\mathrm{um}}\right)$. It coincides with the inclination of sensuality «in so far as it strays from the order of reason» (secundum quod exit ordinem rationis) (ad $3^{\mathrm{um}}$ ). It is extremely interesting that here Thomas speaks of a lex to refer to what is not rational, what is beyond the order of reason, if we consider that it is reason that formally defines the concept of law (ordinatio rationis: I-II,90,1). Thomas, to explain how this is possible, recalls the fact that «the law, as to its essence, resides in him that rules and measures; but, by way of participation in that which is ruled and measured» (I-II,91,6). This allows Thomas to situate lex fomitis in the second instance: that of a subject which is regulated and measured. But of course even here we must distinguish two types of inclinations. There is a natural inclination placed by God in the specific nature of some being: and that inclination of man which is "to act in accordance with reason: and this law was so effective in the primitive state, that nothing either beside or against reason could take man unawares».

But then there's the fall, the drama of sin. How precisely sin can actually happen remains a mystery: if «nothing either beside or against reason could take us unawares», how does one explain the acceptance of something which goes against reason? How do we rationally explain the origin of that which is against reason? This, of course, is the difficulty Kant encounters when he tries to explain the rational origin of what he calls "the radical evil in human nature" and which corresponds to the testimony of Holy Scripture that tries to explain in narrative form the origin of evil: «evil can have originated only from moral evil (not just from the limitations of our nature); yet the original predisposition [...] is a predisposition to the good; there is no conceivable ground for us, there- 
fore, from which moral evil could first have come in us». ${ }^{8}$ According to Kant, the origin of evil in us is therefore rationally incomprehensible. Reason here must recognize its own limits (Grenzen): it can only attest that evil is in man and corrupts the root, but it can not explain from whence derives the principle of evil. Any attempt at rational explanation, in fact, runs into insurmountable aporias.

Thomas also is unable to explain a rationally plausible origin of sin (because it is impossible...), but he reflects on the consequences of it. When man turned away from God, «he fell under the influence of His sensual impulses», and this makes man look like «the beasts that are led by the impulse of sensuality». But while this is perfectly natural for the beasts and is therefore a real natural law (remember the definition of ius naturale in Ulpian: quod natura omnia animalia docuit), for man it is a «deviation from the law of reason». So it is not a law in the proper sense, except in the sense that it is a punishment from God, according to which «man is destitute of original justice, and his reason bereft of its vigor».

Due to the consequences of original sin, man is injured. In I-II,85,3 Thomas, following the authority of Bede, speaks of «the four wounds inflicted on the whole of human nature as a result of our first parent's sin»: the wound of ignorance, of malice, of weakness and of concupiscence (vulnus ignorantiae, malitiae, infirmitatis, concupiscentiae). To the weight of original sin we must then add actual sins, thus producing the following situation: «the reason is obscured (hebetatur), especially in practical matters, the will hardened to evil (induratur ad bonum), good actions become more difficult and concupiscence more impetuous» (I-II,85,3).

Thus man now finds himself concretely within this state of fallen nature and is no longer in his original state in which only reason is the law. Thomas certainly believes that natural law can not be erased from the hearts of men compared to common precepts (I-II,94,6), but «sin blots out the law of nature in particular cases, not universally, except perchance in regard to the secondary precepts of the natural law» (I-II,94,6 ad $1^{\mathrm{um}}$ ). Moreover, it is true that natural law, quantum ad prima principia communia, is the same for all, in a few cases «it may fail, both as to rectitude, by reason of certain obstacles (...), and as to knowledge, since in some the reason is perverted by passion (ex passione), or evil habit (ex mala consuetudine), or an evil disposition of nature (ex mala habitudine naturae)»: the example that Thomas provides in this regard is the fact that «theft, although it is expressly contrary to the natural law, was not

\footnotetext{
8 I. Kant, Religion within the boundaries of mere reason and other writings, p. 64.
} 
considered wrong among the Germans», as Julius Caesar relates in De Bello Gallico (I-II,94,4).

In summary, we can say that the natural law is not some monolithic block which remains undifferentiated; rather, it has inner dimensions which exhibit different perspectives and require different types of knowledge. An understanding of natural law is complete only if it takes into account the historical and concrete circumstances of its realization. The fact that mankind lives in statu naturae lapsae is reflected in the way in which the natural law is known and lived. Thomas is thus clearly far from an abstract and rationalist consideration of reason, which ignores the concrete conditions of the exercise of practical reason by a finite and sinful man.

\section{The natural law and the Old law}

We now move on to consider the relationship between the natural law and the Old law. In Thomas' treatise on the law, he devotes eight questions to the Old law. It is one of the most significant passages of the treatise, for it reveals the particular genius of Aquinas in showing the relationship between the data of revelation and of natural law, between Scripture and human reason.

In quaestio 98 he examines the Old law itself, clarifying its necessity and its inherent value. In dealing with the obligation to observe the commandments, Thomas explains that the Old law «showed forth the precepts of the natural law, and added certain precepts of its own. Accordingly, as to those precepts of the natural law contained in the Old law, all were bound to observe the Old law; not because they belonged to the Old law, but because they belonged to the natural law» (I-II,98,5). And so, in reference to what was derived from the natural law, the Old law was mandatory for all, while the other precepts, derived solely from the Old law were to be observed only by the Jewish people. And it is precisely in relation to this division of the various precepts which Thomas elaborates on in the subsequent quaestiones, in which he deals with Moral precepts, which are identified with the precepts of the natural law (I-II,100), the Ceremonial precepts, which establish divine worship (I-II,101-103), and Judicial precepts, which establish justice among men (I-II,104-105).

It is not possible to analyze here all the details of Thomas' fascinating analysis, so I must limit myself to highlighting three specific aspects.

The first aspect is the role of the Old law in dealing with the sinfulness of man and the fragility of knowledge that comes from sinful habits. Under this aspect, one sees that the law corrects a deviation which in itself - if man had a "pure" rationality - is inconceivable. "Human reason could not go astray in 
the abstract, as to the universal principles of the natural law; but through being habituated to sin, it became obscured on the point of things to be done in detail. But with regard to the other moral precepts, which are like conclusions drawn from the universal principles of the natural law, the reason of many men went astray, to the extent of judging to be lawful things that are evil in themselves. Hence there was need for the authority of the Divine law to rescue man from both these defects» (I-II,99,2 ad $2^{\text {um }}$ ). We see clearly in this passage how Thomas does not diminish the concrete effect of sin on all of human nature.

The second aspect worth mentioning is the consideration of the nature of the moral precepts (I-II,100,1). All of them belong to the natural law, but they are known in different ways: some are immediately evident, while others require either a profound analysis or the dictates of divine teaching. Thus there are three levels of knowing. The first level is the most evident: all men allow, for example, that we must honor our father and mother, that we should not kill, nor steal, etc. These precepts belong to the natural law absolutely. The second level is less evident and requires a more accurate analysis and instruction by wise people. The example that Thomas provides is the following: «Rise up before the hoary head, and honor the person of the aged man». Then there is a third level where there is not, shall we say, rational evidence, and thus there is the need for human reason to be instructed by the teaching of God. The example that Thomas provides is the first tablet of the Decalogue («Thou shalt not make to thyself a graven thing, nor the likeness of anything» and "Thou shalt not take the name of the Lord thy God in vain»). I do not know if the exegetes and moralists of today would agree on the examples used by Thomas, but what I want to emphasize is how, on one hand, he is aware of the distinctions internal to the Decalogue and, on the other hand, the different levels of rational evidence with respect to the individual commandments. To say that the Decalogue coincides tout court with the precepts of the natural law is a simplification that does not take into account the nuances of Thomas' discourse.

The third aspect which should be emphasized is that the entire Old law should be traced to a single end, which is that of friendship, «since every law aims at establishing friendship, either between man and man, or between man and God». For this reason the law can be reduced to this single commandment: «Thou shalt love thy neighbor as thyself» (Rom 13:9), which for Thomas expresses the same thing as what Jesus says in the Gospel of Matthew: «On these two commandments dependeth the whole Law and the prophets» (Mt 22:40) (I-II,99,1, ad 2um). But Thomas goes beyond this expression when he says that the two great commandments of the Old Law, love of God and love of neighbor, «are the first general principles of the natural law, and are self-evident to human reason, either through nature or through faith. Wherefore all the precepts of 
the Decalogue are referred to these, as conclusions to general principles (I-II, $100,3,1)$. Love therefore constitutes the end and also the ultimate evidence of the law.

At this point, some considerations are necessary. First, a question: Is the connection between natural law and the Old Law, despite all the distinctions provided by Thomas, still somehow problematic? Is there not the risk of projecting on natural reason a light which in reality actually comes only by way of revelation? And vice versa: if the natural law in fact coincides with the assertions of the Decalogue, what is the need for and the specific nature of revelation? It seems to me that we can say that Thomas attempts to provide a fruitful circularity between theology and anthropology. On the one hand the natural law comes to be known through the Old law: the latter makes up for the insufficient evidence of the natural law due to the state of fallen nature. In this way the anthropological opens to the theological. But seeing how Thomas equates the moral precepts of the Old Law with those of the natural law, he recognizes the debt of the theological to the anthropological. One cannot, in fact, understand the revelation of God without also connecting it to that which constitutes the profound realities of our humanity.

The divine law is certainly joined to a humanity wounded by sin, but humanity nonetheless retains an orientation to the good. ${ }^{9}$ This orientation to the good - while still fragile - finds its source and its fulfillment in the law of love, as is evident in the discussion of the new law that we will now briefly analyze.

\section{The overflowing fulfilment of Christ's love}

Thomas speaks of the law of the Gospel or the New law (lex nova) as an interior law of the heart, an infused law which is not written. Following the Aristotelian principle, this consists in that which preponderates (potissimum) in it, i.e. "the very grace of the Holy Ghost (ipsa gratia Spiritus Sancti), which is given to those who believe in Christ" (I-II,106,1). Contrary to the Old law, the law of the Gospel justifies, if it is understood precisely in the essential sense of the grace of Holy Spirit (I-II,106,2).

9 As affirmed by von Balthasar in his celebrated Nine Theses in Christian Ethics: «Neither the self-discovery involved in the first insight, nor the strong attraction of particular temporal goods, nor the fact that sin often obscures man's awareness that the good is a gift-none of these can destroy the innate orientation of man to the good. Thus Saint Paul could say that the pagans are judged "by Jesus Christ according to my Gospel" (Rom 2:16)» (Thesis, 7). 
Thomas gives particular attention to this comparison between the Old law and the New law. ${ }^{10}$ These are certainly diverse, not in the sense that they have a different end in view (for the only end is man's subjection to God) but as they are ordered to it in a different way. In fact, the Old law is like a teacher, whereas the New law is a "law of perfection" (lexperfectionis). The Old law, then, is a law of fear" (lex timoris), because it provokes the observance of its commandments by way of the fear of punishment. The New law - given to the perfect, who are those moved to act virtuously for love of virtue - is instead a "law of love" (lex amoris): this moves towards spiritual and eternal realities so that "persons are inclined of themselves to those objects, not as to something foreign but as to something of their own» (I-II,107,1, ad $2^{\text {um }}$ ). This is also called the "law of faith" (lex fidei), because it is given to those who come to believe and also the "law of reality" (lex veritatis) with respect to the Old which is only a shadow. Eventually, Thomas cites the letter of James (1:25) and defines the New law as «the law of perfect liberty» because «the grace of the Holy Ghost is like an interior habit bestowed on us and inclining us to act aright» and «it makes us do freely those things that are becoming to grace, and shun what is opposed to it» (I-II, 108,1, ad 2um).

How does the natural law relate to the law of the Gospel? We could say that Thomas sees the natural law as an alternative to a state of original prelapsarian integrity and also avoids reducing it to the law of the Gospel, as we see in the definition of Decretum Gratiani (ius naturale est quod in lege et evangelio continetur). ${ }^{11}$ He maintains a firm distinction between the diverse stages of salvation history, which correspond to three types of law: Adam (natural law), Moses (Old law), Christ (New law). These stages are not meant to substitute

10 About the role of the thirteenth century theologians in their conception of the relationship between Old and New Law, see E. Marmursztejn, Loi ancienne, loi nouvelle et normes chrétiennes dans la théologie scolastique du XIII siècle, pp. 509-539.

11 Cfr. G. Médevielle, Nature et loi naturelle comme concepts théologiques, pp. 245-265: «D'une part, il ne peut pas conserver certaines conceptions patristiques du droit naturel réservé à une humanité en état d'intégrité originelle pré-lapsaire, symbole d'un âge d’or, indicateur d'un idéal, mais incapables de donner une force aux normes morales édictées par les hommes. D’autre part, il rompt aussi avec la définition de Gratien où, synonyme de la loi évangélique, la loi naturelle semble perdre sa signification et son originalité en sorte qu'il devient superflu de s'y référer dès lors que l’on dispose de l'Évangile. Dans cette théologie, la raison humaine n'est plus envisagée comme une simple pragmatique empirique, mais comme la manifestation dans l'homme de la nature divine. Image de Dieu, participant de la nature divine, l'homme peut par sa raison droite accomplir la volonté de Dieu. Le droit qui régit les rapports entre humains et la bonne nature de l'homme sont alors pensés théologiquement comme l'expression de la présence de la grâce en l'homme» (257). 
simply for one another, since the Old law is accomplished, but not repealed by the New (cfr. Mt 5:17) and the natural law does not simply disappear with the advent of positive divine law: «grace presupposes nature (gratia presupponit naturam), so must the Divine law presuppose the natural law» (I-II,99,2, ad $\left.1^{\text {um }}\right)$. In this sense, the natural law is not autonomous; it is not a law sufficient unto itself, as it was understood in the modern tradition which supposed that agreement among men is possible only by putting God in parentheses (etsi Deus non daretur). The natural law is understandable only within God's unique plan which is progressively realized in moving towards the culmination of love (and therefore not by a theology on two planes in which the natural and supernatural are juxtaposed extrinsically).

Because of this, Matthew Levering is quite right in his affirmation that the novelty of the New law does not render superfluous any reference to the natural law, if it is understood as an expression of our turning toward God, of our being made for God, of the constituent "eccentricity" of our nature, according to the model which he defines as "the pattern of ecstasis". ${ }^{12}$ The profound unity of the plan of God for humanity prevents the division of that which is united to the origin and the separation of that which is "natural" from that which is "evangelical."

Between law and love, or between law and the Gospel, there is neither contrast nor opposition. There is, however, a certain tension, which is clearly seen in Pauline thinking. According to Balthasar, man tries to escape this tension in two contrasting modes: the first way happens when «he tries to make the law (Torah) an absolute that takes the place of the living God» and the «second way to overcome this tension is to consider the law a foreign element and then replace it with promise and hope». ${ }^{13}$ Thomas is well aware that the law cannot be considered the last word which is ultimate and absolute, as shown in the comments he makes in regards to the Pauline affirmation that those who are led by the Spirit are not under the law. ${ }^{14}$ And on the other hand, he does

12 M. Levering, Biblical Natural Law. A Theocentric and Teleological Approach. According to the Author, "viewed from the positive side, biblical revelation not only illumines the mind and will by removing the blinders of sin, but also shows that the "ecstatic" pattern of natural law has been, from the beginning, taken up into the infinitely higher pattern of charity that is the Trinitarian communion» (219). Also, "the pattern of ecstasis, made manifest in the natural law and elevated by grace into personal communion with the Trinity, unifies law and love» (223).

13 Nine Theses in Christian Ethics: Thesis 6.

14 «This saying of the Apostle may be understood in two ways. First, so that a man is said to be under the law, through being pinned down thereby, against his will, as by a load. Hence, on the same passage a gloss says that "he is under the law, who refrains from evil 
not just cancel the law and simply replace it with love, because we have not reached the eschatological fullness. On this point one can cite Luis Malaspina's recent essay which argues that the New law is the definitive hermeneutic of the natural law. ${ }^{15} \mathrm{He}$ insists on the fact that in Thomas the natural law has caritas as its completion and perfection: the end of law, after all, is to make us good (cfr. I-II,92,1) and to lead us to beatitude, which is simply full communion with God. And this is precisely the love of God which the Holy Spirit has poured into our hearts (cfr. Rom 5:5).

These reflections of Thomas on the theme of the New law open a new perspective which is very pertinent as it relates to theology and christology. Contemporary moral theology has highlighted the role of Christ as the «concrete Norm» (Balthasar) and as the «living and personal Law» (Veritatis splendor, 15). The question that one should ask at this point is whether theology has succeeded in thinking of "the nomos of the singularity of Christ"16 - which is completed in the paschal mystery - as a decisive category for clarifying the relationship between the Christological order of grace and the anthropological order of "nature". 17

deeds, through fear of punishment threatened by the law, and not from love of virtue." In this way the spiritual man is not under the law, because he fulfils the law willingly, through charity which is poured into his heart by the Holy Ghost. Secondly, it can be understood as meaning that the works of a man, who is led by the Holy Ghost, are the works of the Holy Ghost rather than his own. Therefore, since the Holy Ghost is not under the law, as neither is the Son, as stated above (Article [4], ad 2); it follows that such works, in so far as they are of the Holy Ghost, are not under the law. The Apostle witnesses to this when he says (2 Cor. 3:17): "Where the Spirit of the Lord is, there is liberty"» (I-II,93,6,ad $1^{\mathrm{um}}$ ).

15 «Incluyéndola sin confundirse con ella (ingrediente), asumiéndola sin destruirla (infraestructura), transfigurándola sin modificarla (subordinación), mediante el dinamismo de la caridad que contiene y que realiza de modo eminente, la ley nueva es la hermenéutica definitiva de la ley natural y el analogatum princeps de la ley moral»: L.D. Malaspina, Tota lex Christi pendet a caritate. La ley nueva, hermenéutica definitiva de la ley natural en la perspectiva de Santo Tomás de Aquino, pp. 509.

16 Cfr. G. Pasquale, La legge morale naturale e il nomos dell'individualità storica di Gesù Cristo, in: R. Gerardi (ed.), La legge morale naturale, pp. 101-112.

17 On this point, the International Theological Commission's document In Search of a Universal Ethic could have been more courageous: S. Zamboni, La legge naturale e la legge nuova, pp. 415-420. 


\section{Conclusion}

Leo Strauss, in his celebrated Natural Right and History, writes that in Thomas one can clearly see that the theme of natural law is «practically inseparable not only from natural theology [...] but even from revealed theology. Modern natural law was partly a reaction to this absorption of natural law by theology». ${ }^{18}$ We must ask ourselves if we who are well placed within the modern tradition might also be a bit embarrassed by the theological nature and context of the natural law in the thought of Thomas. In this sense, one could be a bit perplexed when the document In Search of a Universal Ethic affirms in its conclusion: «The concept of natural law is first of all philosophical» (n. 114).

Just based on the theological nature of his approach, Thomas manages, in my opinion, to propose a thought that avoids the risk on one hand of being excessively rationalist (which forgets the existential conditions of man) and, on the other hand of being excessively fideistic (which detaches charity from the reality which it intends to illuminate). The notion of natural law appears in Thomas as a rational mediation between christian revelation and created reality. ${ }^{19}$ We could say that Aquinas is optimistic about the possibility of human reason to acquire the first principles of the natural law, specifying however that this optimism is not derived from an "autonomous" capacity of reason but comes from the fact that it participates in divine reason, of which it is an impressio. And at the same time, Thomas is very realistic because he considers the actions of man to be situated in an existential context which is marked by the drama of sin which thus renders the first principles of the natural law inoperative in concrete decisions. ${ }^{20}$

Georges Cottier vigorously defends the following: «A rationalist reading of the treatise on natural law is flawed in two primary ways. First, it does not

\section{L. Strauss, Natural Right and History, p. 164.}

19 «Face au dualisme d’un évangélisme illuminé qui détacherait la charité des réalités natives qu'elle doit transfigurer, la référence à la loi naturelle s'interpose comme la médiation rationnelle qui, selon une dialectique d'accomplissement, relie Révélation chrétienne et réalité créationnelle»: Médevielle, Nature et loi naturelle, p. 263.

20 Nonetheless, some authors, such as Giuseppe Angelini, show how in Thomas there remains an intellectualist approach which thinks of man's relationship with the law and with divine revelation as essentially knowledge, and not as a drama of freedom (i.e. "covenant" in biblical terms). For the position of Angelini, see my contribution: La legge morale naturale in G. Angelini, in: M. McKeever, G. Quaranta, Voglio, dunque sono. La teologia morale di Giuseppe Angelini, pp. 201-219. 
give due attention to the distinction between the concepts of essence and nature. Nature, in fact, means the essence, not in its barrenness as essence, but because it is the root of specific activities. With activity, we are in the order of existence, and not in the heights of pure essence. Second, rationalism ignores the real conditions of the exercise of practical reason, which are the conditions of a humanity which bears the marks of original sin and is the object of redeeming grace. One cannot ignore the presence of the lex fomitis in the habitual comportment of humanity, nor can it ignore the difficulty after the fall of man to discern clearly that which is an authentic inclinatio naturae measured by the inclinatio rationis, and that which pertains to the impetus sensualitatis. Naturalism presupposes the absence of this discernment». ${ }^{21}$

Thomas offers us reflections on law which are both extremely valuable and precise, especially because he does not hide all the difficulties inherent within the concept of natural law. I consider these difficulties to be derived not from his social context, which is more coherent in its thought than ours, nor from within reason itself, but from an attentive reading of the salvifichistoric dynamic of Scripture. It is precisely from this drama of salvation present in Scripture that Thomas tries to offer us a model of the natural law which incorporates both a non-competitive vision of the relationship between God and man (the natural law as partecipatio) and also the drama in which man is historically situated.

One sees, in other words, the "disturbing" role of revelation with respect both to tradition and to an abstract reason without time or place. Precisely because Thomas inserts the tradition of the natural law within a historicalsalvific framework, he is thus able to give an account of the tensions, the diffi-

21 «Une lecture rationaliste du traité de la loi naturelle pèche sur deux points majeurs. Premièrement elle ne prête pas l'attention voulue à la distinction entre les concepts d'essence et de nature. La nature signifie, en effet, l'essence, non pas dans sa nudité d'essence, mais en tant qu'elle est la racine d’activités spécifiques. Avec l'activité, nous sommes dans l'ordre de l'exister, et non dans le ciel des pures essences. En second lieu, le rationalisme ignore les conditions réelles d'exercice de la raison pratique, qui sont celles de l'humanité porteuse du péché originel et objet de la grâce rédemptrice. On ne peut ignorer la présence de la lex fomitis dans le comportement habituel de l'humanité ni non plus la difficulté, dans la situation de l'homme après la chute, de discerner clairement ce qui est une authentique inclinatio naturae mesurée par l'inclinatio rationis, et ce qui ressortit à l'impetus sensualitatis. Le naturalisme présuppose l'absence de ce discernement»: G.M. Cottier, Loi naturelle et Décalogue, in: Persona, legge naturale, diritti umani in una società complessa e globale, pp. 23-40. The citation comes from page 35 . It is my translation. 
culties, and the intrinsic dynamic of this concept. ${ }^{22}$ Certainly it is not without its weaknesses, but the Thomistic synthesis remains extremely relevant for today. The paradox in which we find ourselves today seems to be that which Thomas himself saw clearly: we no longer spontaneously understand what in theory should be readily apparent. That which Thomas has highlighted starting from the history of salvation appears today almost as empirical evidence: the encounter between diverse cultures and the overpowering trend of the global market have made it difficult, if not almost impossible, to understand what is the real basis of our humanum. For Thomas, as we have seen, one cannot speak of natural law without accounting for $\sin$, for the status of a fallen nature and therefore of the existential difficulty in identifying the precepts of the natural law. And this difficulty only grows in an increasingly complex and plural world.

Although it may seem paradoxical, the (universal!) fecundity of the Thomistic heritage of natural law seems to be connected to his fidelity to biblical revelation. In this sense, the concept of "revealed morality" on which the Pontifical Biblical Commission's document The Bible and Morality is based appears particularly interesting, as well as the biblical concept of law, which is not primarily a precept but instruction and light for the path of life. ${ }^{23}$ Revelation is not a threat to reason; rather, it makes thought fruitful.

If this is true, then it also appears necessary that moral theology must demonstrate how the natural law is effectively and overflowingly fulfilled only in Christ. Here, perhaps, is where the Thomistic perspective could have been more thorough. Nevertheless, it is certainly a welcome relief that the Commandments appear essentially as an expression of the two fundamental commandments of love of God and love of neighbor. This suggests that love is actually the meaning and purpose of the law, brought to completion

22 Thomas is not afraid to address the "difficult pages of the bible" which appear to contradict the immutability of the natural law, for example the command given to Abraham to sacrifice his son (Gn. 22:2) or the command given to Hosea to take to himself "a wife of fornications" (Os 1:2). I note in passing that based on the sacrifice of Abraham, Kierkegaard claims a "Teleological suspension of the Ethical" based on the fact that «the single individual stands in an absolute relation to the Absolute» (cfr. Fear and trembling, Cambridge University Press, 2006, p. 106). Thomas, in his treatise on the law, returns to these biblical instances on two different occasions (I-II,94,5, ad $2^{\text {um }} ; 100,8$, ad $3^{\text {um }}$ ). Today, we would surely provide a profoundly different exegetical explanation, but what I would like to note is Thomas' honesty in acknowledging that there is at least a tension between the biblical story and "pure" reason.

23 Regarding the concept of "revealed morality", see n. 4, and for "law", see n. 20. 
through the revelation of Christ. Thus, for all those engaged in moral theology, it is urgent to return to Thomas, not so that one can "copy" him (which would be quite untenable), but to appropriate his insights and perspective, in an open dialogue with the contemporary culture and in fidelity to the dynamic of biblical revelation in its Christological fulfillment. ${ }^{24}$

\section{References}

Balthasar H.U. von, Nine Theses in Christian Ethics, in International Theological Commission, Texts and Documents 1969-1985, Ignatius Press 2009, pp. 107-123.

Chiodi M., La tradizione tomista e l'emergenza del moderno, in: G. Angelini (ed.), La legge naturale. I principi dell'umano e la molteplicità delle culture, Glossa, 2007, pp. 63-116.

Cottier G.M., Loi naturelle et Décalogue, in: Persona, legge naturale, diritti umani in una società complessa e globale (Atti della vi sessione plenaria 23-25 giugno 2006): Doctor Communis (2007), pp. 23-40.

Dolan B.M., The Continuing Vitality Of The Catholic Tradition Of Natural Law. Contemporary Catholic Responses to the Critique of Natural Law: The Contributions of Jean Porter and Eberhard Schockenhoff, Accademia Alfonsiana, 2016.

Finnis J., Natural Law and Natural Rights, Oxford University Press, $2011^{2}$.

Finnis J., Aquinas: Moral, Political, and Legal Theory, Oxford University Press, 1998.

Habermas J., Ratzinger J., The Dialectics of Secularization: On Reason and Religion, Ignatius Press, 2006.

International Theological Commission, In Search of a Universal Ethic. A New Look at the Natural Law, 2009.

Kant I., Religion within the boundaries of mere reason and other writings, Cambridge University Press 1998.

Kierkegaard S., Fear and trembling, Cambridge University Press, 2006.

Levering M., Biblical Natural Law. A Theocentric and Teleological Approach, Oxford University Press, 2010.

Malaspina L.D., Tota lex Christi pendet a caritate. La ley nueva, hermenéutica definitiva de la ley natural en la perspectiva de Santo Tomás de Aquino, Agape Libros, 2012.

24 Cfr. M. Chiodi, La tradizione tomista e l'emergenza del moderno, in: G. Angelini (ed.), La legge naturale. I principi dell'umano e la molteplicità delle culture, pp. 63-116: «Il "ritorno a Tommaso" [...] non può essere la sua ripresa letterale, ma dovrebbe coincidere con la ripresa della sua intenzione e della sua impresa [...] in un rinnovato confronto con la cultura ed anche con il sapere filosofico contemporaneo, per pensare oggi la fede nella Rivelazione biblica, nel suo compimento cristologico, non fuori, ma a partire dalle presenti condizioni culturali» (The citation comes from pages 115-116). 
Marmursztejn E., Loi ancienne, loi nouvelle et normes chrétiennes dans la théologie scolastique du XIII e siècle, Revue de l'histoire des religions 228-4/2011, pp. 509539.

McKeever P.E., Theology and Natural Law, Proceedings of the American Catholic Theological Society 21 (1966), pp. 223-237.

Médevielle G., Nature et loi naturelle comme concepts théologiques, Recherches de Science Religieuse 98 (2010), pp. 245-265.

Pasquale G., La legge morale naturale e il nomos dell'individualità storica di Gesù Cristo, in: R. Gerardi (ed.), La legge morale naturale. Problemi e prospettive, Lateran University Press, 2007, pp. 101-112.

Porter J., Natural and Divine Law. Reclaiming the Tradition for Christian Ethics, W.B. Eerdmans, 2005.

Porter J., Nature as Reason. A Thomistic theory of the natural law, W.B. Eerdmans, 2005

Strauss L., Natural Right and History, University of Chicago Press, 1953.

Thomas Aquinas St., The Summa Theologica, Benziger Bros, pp. 1947-1948.

Zamboni S., La legge morale naturale in G. Angelini, in M. McKeever, G. Quaranta, Voglio, dunque sono. La teologia morale di Giuseppe Angelini, EDB, 2011, pp. 201-219.

Zamboni S., La legge naturale e la legge nuova, Rivista di teologia morale 42 (2010) 167, pp. 415-420. 